\title{
Two randomized migraine studies of galcanezumab
}

\section{Effects on patient functioning and disability}

Janet H. Ford, PhD, David W. Ayer, PhD, Qi Zhang, PhD, Jeffrey N. Carter, PhD, Elizabeth Leroux, MD, Vladimir Skljarevski, MD, Sheena K. Aurora, MD, Antje Tockhorn-Heidenreich, MSc, and Richard B. Lipton, MD

Neurology ${ }^{\circledR}$ 2019;93:e508-e517. doi:10.1212/WNL.0000000000007856

\section{Abstract}

\section{Objective}

To evaluate changes from baseline in patient-reported outcomes for measures of functioning and disability among patients with migraine treated with galcanezumab or placebo.

\section{Methods}

Patients with episodic migraine (4-14 monthly migraine headache days) were treated with either galcanezumab (Evaluation of LY2951742 in the Prevention of Episodic Migraine [EVOLVE]-1: $120 \mathrm{mg} \mathrm{n}=210,240 \mathrm{mg} \mathrm{n}=208$; EVOLVE-2: $120 \mathrm{mg} \mathrm{n}=226,240 \mathrm{mg} \mathrm{n}=220$ ) or placebo (EVOLVE-1 n = 425; EVOLVE-2 $n=450$ ) during 6 months of treatment. MigraineSpecific Quality of Life Questionnaire v2.1 (MSQv2.1) measured the effect of migraine on patient functioning (physical and emotional) in 3 domains, and the Migraine Disability Assessment (MIDAS) quantified headache-related disability associated with missed or reduced productivity at work or home and social events. Both were collected at baseline and during the treatment period (MSQv2.1 = monthly; MIDAS = months 3 and 6 only).

\section{Results}

Differences in MSQv2.1 total score least squares (LS) mean change from baseline (month 4-6) for galcanezumab (120 and $240 \mathrm{mg}$, respectively) were superior to placebo (EVOLVE-1 = 7.3 and 6.7 [both $p<0.001]$; EVOLVE-2 $=8.5$ and 7.3 [both $p<0.001])$. Differences were similar for all domain scores $(p<0.001$ for both galcanezumab doses compared with placebo), were observed as early as month 1 , and were sustained for 6 months for most domains. Differences of MIDAS LS mean change from baseline (month 6) for galcanezumab (120 and $240 \mathrm{mg}$, respectively) compared with placebo were: EVOLVE-1 $=-6.3(p<0.001)$ and $-5.2(p=0.002)$; EVOLVE-2 $=-9.2$ and -8.2 (both $p<0.001$ ).

\section{Conclusions}

Patients with episodic migraine treated with galcanezumab reported significant and clinically meaningful improvements in daily functioning and decreased disability compared with patients who received placebo.

\section{Classification of evidence}

This study provides Class II evidence that for patients with migraine, galcanezumab (120 mg or $240 \mathrm{mg}$ ) given once monthly improved functioning and reduced disability.

\section{Correspondence \\ Dr. Ford}

ford_janet@lilly.com

\section{MORE ONLINE}

\section{$\rightarrow$ Class of Evidence \\ Criteria for rating therapeutic and diagnostic studies \\ NPub.org/coe}




\section{Glossary}

DALY = disability-adjusted life-years; EF = Emotional Function; EVOLVE = Evaluation of LY2951742 in the Prevention of Episodic Migraine; HRQoL = health-related quality of life; ICHD-3 beta = International Classification of Headache Disorders-3 beta; IP = investigational product; ITT = intent-to-treat; LS = least squares; MHD = migraine headache days; MID = minimally important differences; MIDAS = Migraine Disability Assessment; MSQv2.1 = Migraine-Specific Quality of Life Questionnaire version 2.1; RFP = Role Function-Preventive; RFR = Role Function-Restrictive.

Migraine is a neurologic disease that is associated with notable disability globally, ranking second for disability-adjusted life-years (DALY), according to the WHO. ${ }^{1}$ People with migraine also experience diminished health-related quality of life (HRQoL), which affects the physical, emotional, and social aspects of daily living. ${ }^{2-5}$ Preventive treatments for migraine should improve HRQoL and reduce headacherelated disability.

Most migraine prevention clinical studies focus on reductions in monthly migraine days or responder rates as primary efficacy measures. The benefits of preventive treatment on HRQoL and disability may go unmeasured. These types of measures are particularly important because they assess the potential benefits of treatment in patient-centered functional terms and, likewise, capture burdens imposed by medicationrelated side effects. ${ }^{2,6}$ Three-quarters of people with migraine have a reduced ability to function during an attack. ${ }^{7}$

For many oral migraine preventive medications, dose is titrated over weeks, and early discontinuation due to lack of efficacy, poor tolerability, or both is common. , $^{8,9}$

This article reports data from 2 randomized, double-blind, placebo-controlled phase 3 studies (Evaluation of LY2951742 in the Prevention of Episodic Migraine [EVOLVE]-1 and EVOLVE-2) with 2 different dose regimens of galcanezumab (120 and $240 \mathrm{mg}$ ), a monoclonal antibody against calcitonin gene-related peptide used in the preventive treatment of episodic migraine. Incorporated into the study protocols, Migraine-Specific Quality of Life Questionnaire v2.1 (MSQv2.1) and Migraine Disability Assessment (MIDAS) instruments were used to measure patient functioning and disability, respectively, during treatment.

\section{Methods}

\section{Study design}

Details of these studies' designs have been described earlier. ${ }^{10,11}$ Briefly, the design was identical for both studies and consisted of 4 periods: initial screening and washout (3-45 days); a prospective lead-in or baseline period for determining the frequency of migraine headache days (MHD) or probable migraine headache (30-40 days); a double-blind treatment period (months 1, 2, 3, 4, 5, and 6); and a 4-month posttreatment (washout) period (months 7, 8, 9, 10). Study treatments (galcanezumab 120 or $240 \mathrm{mg}$ or placebo; randomization ratio was $1: 1: 2$, respectively) were administered monthly during office visits by subcutaneous injection during the double-blind treatment period. Patients used an electronic hand-held diary device to record their headache information, such as pain severity and duration, other related symptoms, and acute medication use. Participants made diary entries every day during the baseline, treatment, and posttreatment periods; patients were also permitted to take specified acute migraine medications during these periods.

\section{Diagnosis}

The patient population consisted of male and female patients aged 18-65 years previously diagnosed with migraine with or without aura per the International Classification of Headache Disorders- 3 beta (ICHD-3 beta) ${ }^{12}$ criteria for at least 1 year prior, and had migraine onset before age 50 years. Patients were enrolled only if they had a frequency of 4-14 MHD, including probable $\mathrm{MHD}$, and at least 2 migraine attacks per month during the lead-in period. Patients with a history of $\geq 15$ headache days per month on average during the last 3 months due to migraine, probable migraine, or any other headache, or who were suspected of having chronic migraine as defined per ICHD-3 beta, were excluded.

\section{Outcome measures}

The MSQv2.1 is a self-administered health status instrument developed to address physical and emotional limitations of specific concern to people with migraine. ${ }^{13,14}$ It assesses the effect of migraine on work or daily activities, relationships with family and friends, leisure time, productivity, concentration, energy, tiredness, and feelings. ${ }^{13,14}$ The instrument consists of 14 items spanning 3 domains and each dimension is scored independently: (1) Role Function-Restrictive (RFR); (2) Role Function-Preventive (RFP); and (3) Emotional Function (EF). The RFR domain has 7 items that measure the degree to which migraine limits the performance of usual activities, RFP has 4 items that measure the degree to which migraine interrupts or stops the performance of usual activities, and EF has 3 items addressing feelings of frustration and helplessness due to migraine. ${ }^{13,14}$ Participants rated the items on a standard 6-point ordered-categorical scale; answer choices ranged from "none of the time" to "all of the time."13 The MSQv2.1 domains and total raw scores were transformed to ranges of $0-100$, with 100 indicating the best functional health status and a positive change in scores reflecting functional improvement. The transformation process allowed each rating to reflect the percentage of the total possible score. ${ }^{15,16}$ The MSQv2.1 covers a 4-week recall period and is 
considered reliable, valid, and sensitive to changes in migraine effects. ${ }^{13,14}$ It has been used in numerous clinical studies, ${ }^{13,17-21}$ and has been highly recommended by the $\mathrm{NIH}$ as an instrument for headache studies. ${ }^{22}$ Minimally important differences (MID) from baseline (individual-level, within-group) have been established for MSQv2.1 scale scores $(\mathrm{RFR}=+10.9$; $\mathrm{RFP}=+8.3 ; \mathrm{EF}=+12.2) .{ }^{18,23}$

The Migraine Disability Assessment (MIDAS) test was designed to quantify headache-related disability over a 3-month period. ${ }^{24}$ This instrument consists of 5 items that reflect the number of days reported as missing work, or with reduced productivity at work or home, or missing social events. A higher value is indicative of greater disability and scores range from 0 to $270 .^{24,25}$ Categorical grades have been defined for MIDAS. ${ }^{7}$ Grade I = little or no disability (scores of $0-5)$; grade II = mild disability (scores of 6-10); grade III = moderate disability (scores of 11-20); and grade IV = severe disability (scores of 21 or greater). This instrument is considered valid and highly reliable, and correlates well with clinical judgment regarding the need for medical care. ${ }^{24,25}$

Data relative to MSQv2.1 were collected monthly during the double-blind treatment period in both studies while MIDAS data were collected at months 3 and 6 only.

\section{Data analysis}

The primary outcome for each study was overall mean change from baseline in the number of monthly MHD. ${ }^{10,11} \mathrm{Sec}-$ ondary outcomes, the focus of this article, included mean change from baseline on the MSQv2.1 scale (baseline to average of months 4-6), and mean change from baseline on the MIDAS scale (baseline to month 6). MIDAS response was defined as an improvement of at least 50\% from baseline at month 6 in the total score.

Changes from baseline to each postbaseline visit for MSQv2.1 and MIDAS were analyzed using the mixed model repeated measures analysis method (covariates included treatment, region, month, treatment-by-month interaction, baseline value, baseline-by-month interaction, and baseline $\mathrm{MHD}[<8$ vs $\geq 8]$ category). The MSQv2.1 RFR domain was prespecified as the key secondary objective to adjust for multiple testing ${ }^{10,11}$; no multiplicity adjustments were made for other MSQv2.1 domains or MIDAS scores.

The percentages of patients reaching an MSQv2.1 MID over the mean of months 4-6 were analyzed. The percentages of patients reaching a MIDAS total score response of at least $50 \%$ improvement from baseline were calculated. The percentages of patients reaching MIDAS response and reaching MSQv2.1 MID at each postbaseline visit were analyzed with a pseudo-likelihood-based generalized linear mixed models repeated measures approach. Contrasts were used to test for differences in outcomes between treatment groups at each month as well as overall across all months. Statistical tests comparing outcomes between groups assumed a null hypothesis of no difference in outcomes among groups. All $p$ values shown are 2 -sided unless otherwise specifically indicated.

Analyses (SAS software version 9.4, SAS Institute, Cary, NC) included all intent-to-treat (ITT) patients who were randomized and received at least one dose of investigational product (IP).

\section{Primary research question}

Does treatment with galcanezumab for prevention of migraine significantly improve patient functioning and decrease patient disability? These 2 phase 3 clinical trials provide Class II evidence that galcanezumab increases patients' MSQv2.1 scores and decreases MIDAS scores.

\section{Standard protocol approvals, registrations, and patient consents}

These studies are registered with ClinicalTrials.gov (NCT02614183 and NCT02614196). Appropriate institutional review boards at each study site reviewed and approved the study protocols, and all trials were conducted according to Good Clinical Practice and the Declaration of Helsinki. Patients provided written informed consent before initiating study procedures.

\section{Data availability statement}

The studies were registered at ClinicalTrials.gov and those data are available using the following identifiers: NCT02614183; NCT02614196.

\section{Results}

\section{Patients}

Baseline demographics and disease burden are shown in table 1 .

\section{EVOLVE-1}

A total of 1,671 patients with episodic migraine entered the study; 862 were randomized to treatments. A total of 858 randomized patients received at least one dose of IP and were included in the ITT population ( $120 \mathrm{mg} \mathrm{n}=213,240 \mathrm{mg}$ $\mathrm{n}=212$, placebo $\mathrm{n}=433)$. Overall, 703 patients $(81.9 \%$ [703/858]) with episodic migraine completed treatment.

\section{EVOLVE-2}

A total of 1,696 patients entered the study; 922 were randomized to treatments. A total of 915 randomized patients received at least one dose of IP and were included in the ITT population $(120 \mathrm{mg} \mathrm{n}=231,240 \mathrm{mg} \mathrm{n}=223$, placebo $\mathrm{n}=$ 461). Overall, 785 patients (85.1\% [785/922]) completed treatment. In both studies, the most common reason for screen failure was not meeting enrollment criteria based on migraine headache information collected in the electronic patient-reported diary during lead-in.

Mean baseline MSQv2.1 total scores were significantly different between galcanezumab and placebo for EVOLVE-1, 
Table 1 Baseline demographics and disease burden

\begin{tabular}{|c|c|c|c|c|c|c|}
\hline & \multicolumn{3}{|l|}{ EVOLVE-1 } & \multicolumn{3}{|l|}{ EVOLVE-2 } \\
\hline & \multirow[b]{2}{*}{$\begin{array}{l}\text { Placebo, } \\
n=433\end{array}$} & \multicolumn{2}{|c|}{ Galcanezumab } & \multirow[b]{2}{*}{$\begin{array}{l}\text { Placebo, } \\
n=461\end{array}$} & \multicolumn{2}{|c|}{ Galcanezumab } \\
\hline & & $\begin{array}{l}120 \mathrm{mg} \\
n=213\end{array}$ & $\begin{array}{l}240 \mathrm{mg} \\
\mathrm{n}=212\end{array}$ & & $\begin{array}{l}120 \mathrm{mg} \\
\mathrm{n}=231\end{array}$ & $\begin{array}{l}240 \mathrm{mg} \\
\mathrm{n}=223\end{array}$ \\
\hline Age, y, mean (SD) & $41.3(11.4)$ & $40.9(11.9)$ & $39.1(11.5)$ & $42.3(11.3)$ & 40.9 (11.2) & $41.9(10.8)$ \\
\hline Sex (female), \% & 83.6 & 85.0 & 82.6 & 85.3 & 85.3 & 85.7 \\
\hline Race (white), \% & 82.2 & 79.3 & 77.8 & 70.5 & 71.9 & 68.2 \\
\hline MSQv2.1 ${ }^{\mathrm{a}}$ & $N=431$ & $N=212$ & $N=208$ & $N=456$ & $N=231$ & $N=222$ \\
\hline Total, mean (SD) & $59.6(16.1)$ & $56.9(16.7)^{\mathrm{b}}$ & $54.6(17.8)^{c}$ & $58.0(16.7)$ & $59.6(15.3)$ & $58.0(16.8)$ \\
\hline RFR, mean (SD) & $52.9(15.4)$ & $51.4(16.2)$ & $48.8(16.8)^{b}$ & $51.4(15.7)$ & $52.5(14.8)$ & $51.7(16.3)$ \\
\hline RFP, mean (SD) & $69.0(17.9)$ & $65.6(19.3)^{b}$ & $64.4(20.1)^{b}$ & $66.9(19.0)$ & $69.4(18.9)$ & $67.0(20.1)$ \\
\hline EF, mean (SD) & $62.5(24.0)$ & $57.1(24.6)^{b}$ & $55.3(25.4)^{c}$ & $61.7(25.1)$ & $63.4(22.2)$ & $60.7(23.3)$ \\
\hline MIDAS & $N=431$ & $N=212$ & $N=208$ & $N=456$ & $N=231$ & $N=222$ \\
\hline Total, mean (SD) & $31.8(27.3)$ & $32.9(28.2)$ & $36.1(27.8)$ & $34.3(31.0)$ & 30.9 (27.9) & $32.8(28.8)$ \\
\hline No. of days missed work or school & $2.7(4.1)$ & $2.7(3.8)$ & $3.3(5.5)$ & $2.8(5.9)$ & $2.1(3.9)$ & $2.8(4.6)$ \\
\hline No. of days reduced productivity & $7.4(9.0)$ & $6.9(8.0)$ & $8.3(9.5)$ & $8.3(10.0)$ & $7.3(8.2)$ & $8.7(9.7)$ \\
\hline No. of days missed household work & $9.2(8.9)$ & $9.5(9.1)$ & $10.4(9.4)$ & $9.2(9.5)$ & $8.6(9.7)$ & $8.5(9.1)$ \\
\hline No. of days reduced productivity & $8.0(7.7)$ & $8.8(9.3)$ & $8.9(8.4)$ & $8.3(9.1)$ & $8.3(9.4)$ & $8.0(9.3)$ \\
\hline No. of days missed family/social & $4.6(5.6)$ & $5.0(6.6)$ & $5.2(5.0)$ & $5.6(7.4)$ & $4.6(6.8)$ & $4.8(5.4)$ \\
\hline \multicolumn{7}{|c|}{$\begin{array}{l}\text { Abbreviations: EF = emotional function; EVOLVE = Evaluation of LY2951742 in the Prevention of Episodic Migraine; MIDAS = Migraine Disability Assessment; } \\
\text { MSQV2.1 = Migraine-Specific Quality of Life Questionnaire version 2.1; RFP = Role Function-Preventive; RFR = Role Function-Restrictive. } \\
\text { a Total and each domain's raw dimension scores were transformed to a 0- to 100-point scale. } \\
{ }^{\mathrm{b}} p<0.05 \text { Compared with placebo. } \\
\text { c } p<0.001 \text { Compared with placebo. }\end{array}$} \\
\hline
\end{tabular}

but did not differ for EVOLVE-2 (table 1). Baseline scores for MIDAS did not differ significantly between groups.

\section{HRQOL and daily functioning: MSQv2.1}

\section{EVOLVE-1}

After multiplicity adjustment, there was a significantly greater least squares (LS) mean change from baseline relative to placebo $(p<0.001)$ on the RFR domain score in both the galcanezumab $120 \mathrm{mg}$ and $240 \mathrm{mg}$ treatment groups (table 2). Similarly, both galcanezumab doses demonstrated superiority in other domains of MSQv2.1 (table 2). MSQ responses, taken monthly during treatment, demonstrated that galcanezumab significantly $(p<0.001)$ improved RFR (with multiplicity adjustment) scores beginning at month 1 , compared with placebo (figure 1A). Galcanezumab treatment produced a greater proportion of patients who met the established MID criteria at month 6 for MSQv2.1 domains compared to treatment with placebo. For each domain, these data represent the percentage of patients in each treatment group (120 mg, $240 \mathrm{mg}$, placebo, respectively) that met the criteria \pm standard error, and level of significance for the 120 - or $240-\mathrm{mg}$ treatment group compared with placebo. RFR: $89.3 \% \pm 0.02 \%(p=0.004) ; 90.7 \% \pm 0.02 \%(p=0.001)$;
79.7\% \pm 0.02\%. RFP: $85.4 \% \pm 0.03 \%(p=0.003) ; 82.0 \% \pm$ $0.03 \%(p=0.037) ; 72.7 \% \pm 0.03 \%$. EF: $83.2 \% \pm 0.04 \%(p=$ $0.012) ; 85.8 \% \pm 0.04 \%(p=0.003) ; 69.4 \% \pm 0.04$.

\section{EVOLVE-2}

Both doses of galcanezumab improved daily functioning as measured in each domain of the MSQv2.1 (table 2). Both galcanezumab $120 \mathrm{mg}$ and $240 \mathrm{mg}$ significantly $(p<0.001)$ increased the LS means and difference vs placebo on the RFR (with multiplicity adjustment), RFP, and EF domains, as well as the total score averaged over months 4-6. Moreover, both treatment groups of galcanezumab showed significant improvements $(p<0.001)$ in RFR scores (with multiplicity adjustment) when assessed monthly during treatment (months 1-6) beginning at month 1 compared with placebo (figure 1b). As shown in EVOLVE-1, the proportion of patients who met the established MID criteria at month 6 for MSQv2.1 domains was greater with galcanezumab than with placebo, and the differences for all MSQv2.1 domains and both galcanezumab treatment groups compared with placebo were significant. Data are reported here in the same format as above in EVOLVE-1. RFR: $90.6 \% \pm 0.02 \%$ $(p<0.001) ; 87.6 \% \pm 0.02 \%(p<0.001) ; 74.5 \% \pm 0.02 \%$. RFP: $82.5 \% \pm 0.03 \%(p<0.001) ; 79.4 \% \pm 0.03 \%(p=0.004)$; 
Table 2 Changes in patient functioning and disability scores during treatment

\begin{tabular}{|c|c|c|c|c|c|c|}
\hline & \multicolumn{3}{|l|}{ EVOLVE-1 } & \multicolumn{3}{|l|}{ EVOLVE-2 } \\
\hline & \multirow[b]{2}{*}{$\begin{array}{l}\text { Placebo, } \\
n=425\end{array}$} & \multicolumn{2}{|c|}{ Galcanezumab } & \multirow[b]{2}{*}{$\begin{array}{l}\text { Placebo, } \\
n=450\end{array}$} & \multicolumn{2}{|c|}{ Galcanezumab } \\
\hline & & $\begin{array}{l}120 \mathrm{mg}, \\
\mathrm{n}=210\end{array}$ & $\begin{array}{l}240 \mathrm{mg} \\
\mathrm{n}=208\end{array}$ & & $\begin{array}{l}120 \mathrm{mg} \\
\mathrm{n}=226\end{array}$ & $\begin{array}{l}240 \mathrm{mg} \\
\mathrm{n}=220\end{array}$ \\
\hline \multicolumn{7}{|c|}{ MSQv2.1 total (average of months 4-6) } \\
\hline LS mean change (SE) & $21.5(1.0)$ & $28.9(1.3)^{\mathrm{b}}$ & $28.2(1.3)^{\mathrm{b}}$ & $16.6(0.9)$ & $25.0(1.1)^{\mathrm{b}}$ & $23.9(1.1)^{\mathrm{b}}$ \\
\hline Diff vs placebo (SE) & - & $7.3(1.2)^{\mathrm{b}}$ & $6.7(1.3)^{\mathrm{b}}$ & - & $8.5(1.2)^{\mathrm{b}}$ & $7.3(1.2)^{b}$ \\
\hline $95 \% \mathrm{Cl}$ & - & $4.9,9.8$ & $4.3,9.2$ & - & $6.1,10.8$ & $5.0,9.6$ \\
\hline \multicolumn{7}{|c|}{ RFR (average of months 4-6) } \\
\hline LS mean change (SE) & $24.7(1.1)$ & $32.4(1.3)^{b}$ & $32.1(1.3)^{b}$ & $19.7(0.9)$ & $28.5(1.2)^{b}$ & $27.0(1.2)^{\mathrm{b}}$ \\
\hline Diff vs placebo (SE) & - & $7.7(1.3)^{b}$ & $7.4(1.3)^{\mathrm{b}}$ & - & $8.8(1.3)^{\mathrm{b}}$ & $7.4(1.3)^{\mathrm{b}}$ \\
\hline $95 \% \mathrm{Cl}$ & - & $5.2,10.3$ & $4.8,10.0$ & - & $6.3,11.3$ & $4.9,9.9$ \\
\hline \multicolumn{7}{|c|}{ RFP (average of months 4-6) } \\
\hline LS mean change (SE) & $17.1(0.9)$ & $22.7(1.2)^{\mathrm{b}}$ & $21.8(1.2)^{\mathrm{b}}$ & $12.3(0.8)$ & $20.1(1.0)^{b}$ & $18.9(1.1)^{\mathrm{b}}$ \\
\hline Diff vs placebo (SE) & - & $5.6(1.1)^{b}$ & $4.7(1.2)^{b}$ & - & $7.8(1.1)^{b}$ & $6.7(1.1)^{b}$ \\
\hline $95 \% \mathrm{Cl}$ & - & $3.3,7.8$ & $2.4,7.0$ & - & $5.6,10.1$ & $4.4,8.9$ \\
\hline \multicolumn{7}{|c|}{ EF (average of months 4-6) } \\
\hline LS mean change (SE) & $20.7(1.3)$ & $29.0(1.5)^{b}$ & $27.9(1.6)^{b}$ & $15.6(1.0)$ & $24.1(1.3)^{\mathrm{b}}$ & $23.4(1.3)^{b}$ \\
\hline Diff vs placebo (SE) & - & $8.3(1.5)^{b}$ & $7.2(1.5)^{b}$ & - & $8.5(1.4)^{b}$ & $7.8(1.4)^{\mathrm{b}}$ \\
\hline $95 \% \mathrm{Cl}$ & - & $5.3,11.3$ & $4.1,10.2$ & - & $5.8,11.2$ & $5.1,10.6$ \\
\hline \multicolumn{7}{|l|}{ MIDAS total (month 6) } \\
\hline LS mean change (SE) & $-14.9(1.4)^{b}$ & $-21.2(1.7)^{b}$ & $-20.1(1.7)^{\mathrm{b}}$ & $-12.0(1.3)^{b}$ & $-21.2(1.6)^{b}$ & $-20.2(1.6)^{b}$ \\
\hline Diff vs placebo (SE) & - & $-6.3(1.6)^{b}$ & $-5.2(1.6)^{a}$ & - & $-9.2(1.8)^{b}$ & $-8.2(1.8)^{b}$ \\
\hline $95 \% \mathrm{Cl}$ & - & $-9.5,-3.1$ & $-8.4,-2.0$ & - & $-12.6,-5.7$ & $-11.7,-4.7$ \\
\hline \multicolumn{7}{|c|}{ MIDAS no. of days missed work or school (month 6) } \\
\hline LS mean change (SE) & $-1.0(0.3)^{b}$ & $-1.5(0.3)^{b}$ & $-1.6(0.3)^{b}$ & $-0.8(0.2)^{b}$ & $-1.7(0.3)^{b}$ & $-1.7(0.3)^{b}$ \\
\hline Diff vs placebo (SE) & - & $-0.5(0.3)$ & $-0.6(0.3)$ & - & $-0.9(0.3)^{a}$ & $-0.9(0.3)^{a}$ \\
\hline $95 \% \mathrm{Cl}$ & - & $-1.1,0.1$ & $-1.2,0.1$ & - & $-1.5,-0.4$ & $-1.5,-0.3$ \\
\hline
\end{tabular}

MIDAS no. of days reduced productivity at work or school (month 6)

\begin{tabular}{|c|c|c|c|c|c|c|}
\hline LS mean change (SE) & $-3.3(0.4)^{\mathrm{b}}$ & $-4.8(0.5)^{b}$ & $-5.1(0.5)^{b}$ & $-3.1(0.4)^{b}$ & $-4.9(0.4)^{b}$ & $-5.2(0.4)^{b}$ \\
\hline Diff vs placebo (SE) & - & $-1.5(0.5)^{a}$ & $-1.7(0.5)^{b}$ & - & $-1.9(0.5)^{b}$ & $-2.1(0.5)^{b}$ \\
\hline $95 \% \mathrm{Cl}$ & - & $-2.5,-0.5$ & $-2.7,-0.7$ & - & $-2.8,-0.9$ & $-3.0,-1.1$ \\
\hline \multicolumn{7}{|c|}{ MIDAS no. of days missed household work (month 6) } \\
\hline LS mean change (SE) & $-4.5(0.4)^{b}$ & $-6.2(0.5)^{b}$ & $-6.1(0.5)^{b}$ & $-3.4(0.4)^{b}$ & $-5.9(0.5)^{b}$ & $-5.6(0.5)^{b}$ \\
\hline Diff vs placebo (SE) & - & $-1.7(0.5)^{b}$ & $-1.6(0.5)^{\mathrm{a}}$ & - & $-2.5(0.6)^{b}$ & $-2.2(0.6)^{b}$ \\
\hline $95 \% \mathrm{Cl}$ & - & $-2.7,-0.8$ & $-2.6,-0.7$ & - & $-3.6,-1.4$ & $-3.3,-1.1$ \\
\hline
\end{tabular}

MIDAS no. of days reduced productivity in household work (month 6)

LS mean change (SE)

$-4.4(0.4)^{\mathrm{b}} \quad-5.8(0.5)^{\mathrm{b}} \quad-5.2(0.5)^{\mathrm{b}}$

$-3.3(0.3)^{b}$

$-5.5(0.4)^{b}$

$-5.4(0.4)^{b}$ 
Table 2 Changes in patient functioning and disability scores during treatment (continued)

\begin{tabular}{|c|c|c|c|c|c|c|}
\hline & \multicolumn{3}{|l|}{ EVOLVE-1 } & \multicolumn{3}{|l|}{ EVOLVE-2 } \\
\hline & \multirow[b]{2}{*}{$\begin{array}{l}\text { Placebo, } \\
n=425\end{array}$} & \multicolumn{2}{|c|}{ Galcanezumab } & \multirow[b]{2}{*}{$\begin{array}{l}\text { Placebo, } \\
n=450\end{array}$} & \multicolumn{2}{|c|}{ Galcanezumab } \\
\hline & & $\begin{array}{l}120 \mathrm{mg} \\
\mathrm{n}=210\end{array}$ & $\begin{array}{l}240 \mathrm{mg} \\
\mathrm{n}=208\end{array}$ & & $\begin{array}{l}120 \mathrm{mg} \\
\mathrm{n}=226\end{array}$ & $\begin{array}{l}240 \mathrm{mg} \\
\mathrm{n}=220\end{array}$ \\
\hline Diff vs placebo (SE) & - & $-1.4(0.6)^{a}$ & $-0.8(0.6)$ & - & $-2.2(0.4)^{b}$ & $-2.0(0.4)^{\mathrm{b}}$ \\
\hline $95 \% \mathrm{Cl}$ & - & $-2.5,-0.3$ & $-1.9,0.3$ & - & $-3.0,-1.3$ & $-2.9,-1.2$ \\
\hline \multicolumn{7}{|c|}{ MIDAS no. of days missed family/social (month 6) } \\
\hline LS mean change (SE) & $-2.4(0.3)^{b}$ & $-3.5(0.3)^{b}$ & $-2.6(0.4)^{b}$ & $-1.7(0.3)^{b}$ & $-3.6(0.4)^{b}$ & $-3.0(0.4)^{\mathrm{b}}$ \\
\hline Diff vs placebo (SE) & - & $-1.1(0.3)^{a}$ & $-0.2(0.4)$ & - & $-1.9(0.5)^{b}$ & $-1.2(0.5)^{a}$ \\
\hline $95 \% \mathrm{Cl}$ & - & $-1.8,-0.4$ & $-0.9,0.5$ & - & $-2.8,-0.9$ & $-2.2,-0.3$ \\
\hline \multicolumn{7}{|c|}{$\begin{array}{l}\text { Abbreviations: } \mathrm{Cl}=\text { confidence interval; Diff = difference; } \mathrm{EF}=\text { emotional function; EVOLVE = Evaluation of LY2951742 in the Prevention of Episodic Migraine; } L S \\
=\text { least squares; MIDAS = Migraine Disability Assessment; MSQv2.1 = Migraine-Specific Quality of Life Questionnaire v2.1; RFP = Role Function-Preventive; RFR } \\
\text { = Role Function-Restrictive. } \\
\text { a } p<0.05 \\
{ }^{\mathrm{b}} p<0.001 .\end{array}$} \\
\hline
\end{tabular}

$66.5 \% \pm 0.03 \% . \mathrm{EF}: 78.1 \% \pm 0.04 \%(p=0.002) ; 79.3 \% \pm$ $0.04 \%(p=0.001) ; 62.3 \% \pm 0.03 \%$.

\section{Disability: MIDAS}

\section{EVOLVE-1}

Mean baseline MIDAS total score overall was 33.2, which represented the total number of days migraine limited activity during the previous 3-month period, and reflected severe disability. For MIDAS total score, the percentage of patients meeting the definition of 50\% response at month 6 (model estimated rate) was significantly greater in both the galcanezumab 120 and $240 \mathrm{mg}$ treatment groups ( $80.3 \%$ and $76.2 \%$, respectively; each $p<0.001)$ compared with placebo (54.8\%). Galcanezumab treatment significantly improved individual item scores of the MIDAS $(p<0.001)$ (table 2$)$. Exceptions that were not significantly improved included the following (difference vs placebo only): number of days missed for work or school (120 and $240 \mathrm{mg}$ ); number of days with reduced productivity in household work $(240 \mathrm{mg})$; and number of days missed for family/social activities $(240 \mathrm{mg}$ ). Treatment with galcanezumab significantly improved $(p<$ 0.01) MIDAS total LS mean change from baseline scores compared with placebo at months 3 and 6 (figure 2A).

Figure 1 Galcanezumab treatment improves Role Function-Restrictive domain scores of the Migraine-Specific Quality of Life Questionnaire

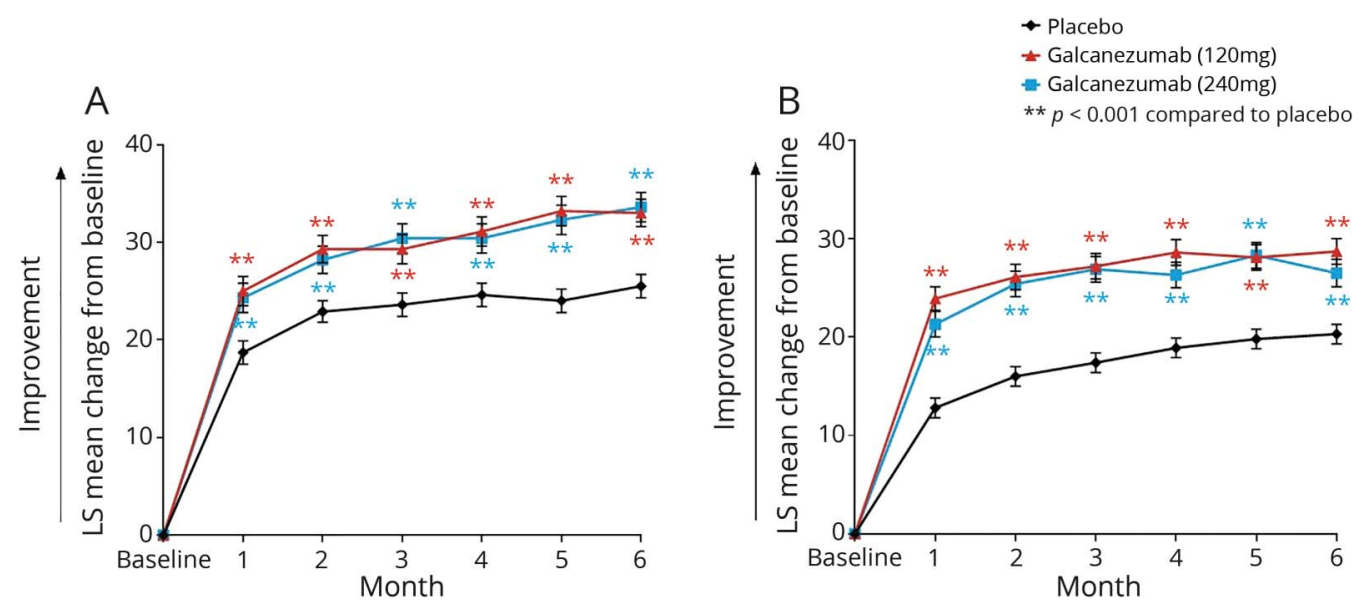

Least squares (LS) mean change from baseline \pm standard error for migraine-specific quality of life (MSQ) questionnaire scores for the Role FunctionRestrictive (RFR) domain are shown for Evaluation of LY2951742 in the Prevention of Episodic Migraine (EVOLVE)-1 (A) and EVOLVE-2 (B). MSQ scores were collected monthly for patients treated with placebo (black diamonds), 120 mg galcanezumab (red triangles), and 240 mg galcanezumab (blue squares). In both trials, patients treated with either dose of galcanezumab had significantly higher scores compared to placebo as early as 1 month after starting treatment. 

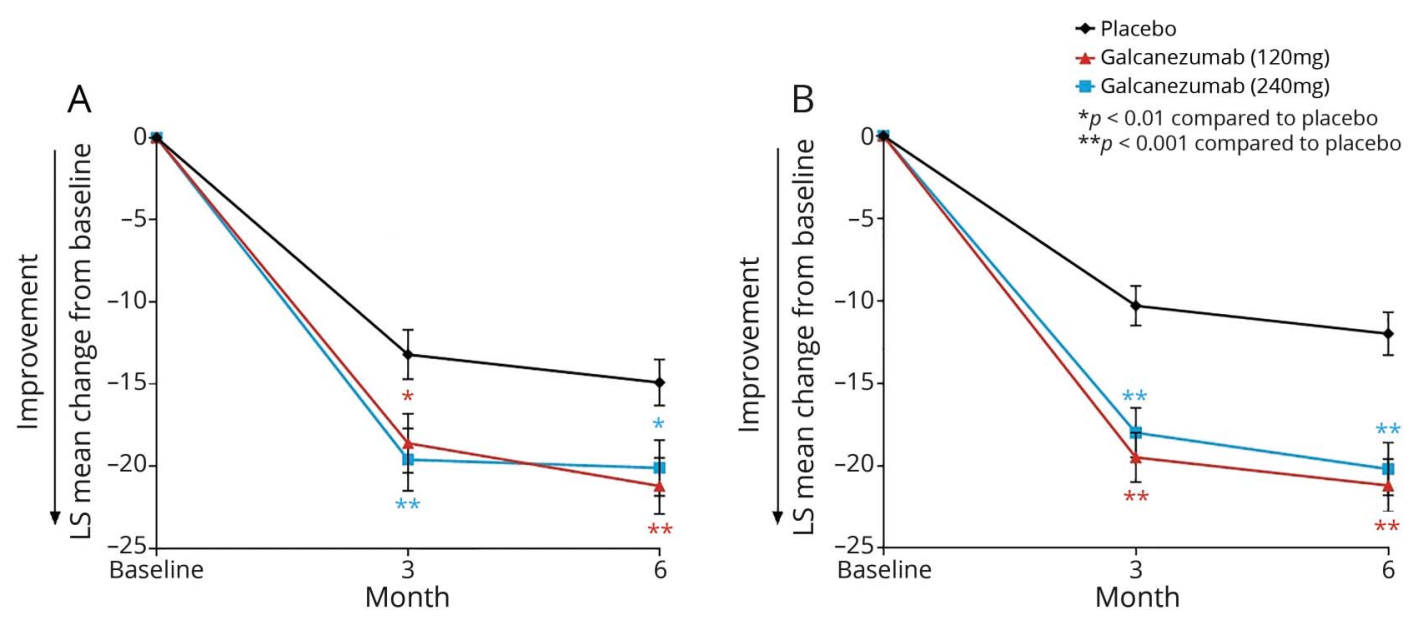

Least squares (LS) mean changes from baseline \pm standard error for the MIDAS total score are shown for Evaluation of LY2951742 in the Prevention of Episodic Migraine (EVOLVE)-1 (A) and EVOLVE-2 (B). MIDAS scores were collected at baseline and at months 3 and 6 for patients treated with placebo (black diamonds), $120 \mathrm{mg}$ galcanezumab (red triangles), and $240 \mathrm{mg}$ galcanezumab (blue squares). In both trials, patients treated with either dose of galcanezumab showed significantly improved MIDAS scores in comparison to patients treated with placebo.

\section{EVOLVE-2}

Mean baseline MIDAS total score overall was 33.0, which again reflected severe disability. For MIDAS total score, the percentage of patients meeting the definition of $50 \%$ response at month 6 (model estimated rate) was statistically greater in both the galcanezumab 120 and $240 \mathrm{mg}$ treatment groups (73.0\% and $77.1 \%$, respectively; each $p<0.001$ ) compared with placebo (55.6\%). Galcanezumab treatment significantly improved all individual item scores of MIDAS $(p<0.05)$ (table 2). Both galcanezumab doses significantly $(p<0.001)$ improved MIDAS total scores at month 6 compared with placebo (figure $2 b$ ).

\section{Discussion}

Measures of HRQoL and measures of disability are related in that high levels of disability are typically accompanied by low HRQoL scores. ${ }^{26}$ Conversely, when effective treatment interventions are used, disability decreases, and HRQoL scores increase. ${ }^{26}$ This distinct interaction between a person's health and the way in which they live and function on a daily basis $^{26}$ is becoming increasingly relevant to clinicians who treat people with migraine.

Both of these studies compared 2 doses of galcanezumab with placebo in the preventive treatment of episodic migraine. Prior publications ${ }^{10,11}$ showed significant reductions in monthly MHD with corresponding significant increases in 50\% responder rates, and low discontinuation rates with evidence of safety and tolerability for both doses of galcanezumab vs placebo. We extended prior analyses and demonstrated significant improvements in HRQoL as measured by the MSQv.2.1, in addition to significant reductions in migrainerelated disability (MIDAS).
At baseline, patients reported MSQv2.1 scores of less than $60 \%$, which indicated considerable functional impairment due to migraine on daily activities over the last 4 weeks. After 6 months of galcanezumab treatment, patients' MSQv2.1 total scores in both studies increased by $23.0-28.9$ points, with consistent significant improvements greater than those seen with placebo for the total score and all 3 domain scores. Galcanezumab-treated patients reported significantly improved MSQv2.1 outcomes compared with patients using placebo, beginning at month 1 and lasting for the duration of the study. On average (months 4-6), patients exceeded approximately $80 \%$ of the total score possible for the MSQv2.1, indicating substantial increases in functional capabilities related to work or daily activities, relationships with family and friends, leisure time, productivity, concentration, energy, tiredness, and emotional well-being. These results were consistent across all 3 domains of MSQv2.1. In the galcanezumab treatment groups, $80 \%$ or more of patients achieved previously defined MIDs after 6 months of treatment. These results indicate that galcanezumab reduced the effect of migraine to restrict, prevent, and emotionally impair patient functioning, beginning at month 1 . A fairly high proportion of placebo patients also met these thresholds, indicating the need to develop and apply responder thresholds using methods deemed acceptable per the Food and Drug Administration PRO Guidance. ${ }^{27}$ Such analyses have been completed and reported for the RFR domain for the galcanezumab double-blind randomized phase 3 clinical trials ${ }^{28}$; however, thresholds for the other 2 domains are still in development.

Baseline MIDAS Total scores indicated that study participants were severely disabled due to migraine. There were significantly greater reductions in MIDAS Total score among patients treated with galcanezumab, with grade-level changes 
from severe to borderline mild/moderate disability after 3 and 6 months of treatment. Survey areas with consistent statistically significant reductions greater than those seen with placebo included productivity at work or school and days of missed household work. Nearly consistent results were observed for the number of days with reduced productivity in household work and days of missed family or social activities. There were greater numerical reductions in days missed at work or school and, given that patients with migraine tend to work through their attacks, ${ }^{5}$ the lack of statistical differences for this particular item was not unexpected. A reduction of $50 \%$ in the MIDAS total score was defined a priori to indicate response, and generally exceeds the threshold of a clinically meaningful change of at least 5 points. More than $70 \%$ of patients in the galcanezumab treatment groups met this responder definition, which was nearly $20 \%$ more than that observed for the placebo treatment group. Total MIDAS scores correlate with clinical judgment of pain intensity, disability, and the level of urgency for treatment in patients with migraine. In these 2 clinical trials, galcanezumab-treated patients experienced shifts from severe to nearly mild disability grades in MIDAS, indicating that treatment needs were being addressed. ${ }^{7}$

A successful preventive therapy for migraine must improve a patient's ability to function across all areas of their life, as well as reduce MHD with minimal or no adverse effects. As previously noted, migraine ranks second in DALY globally, ${ }^{1}$ with high indirect costs attributed to reduced productivity. Patients report that migraine impairs daily functioning in multiple areas of their lives ${ }^{3,29-31}$ and even moderate migraine attacks can disturb patients' normal activities. ${ }^{3}$ According to patient reports, work difficulties are mostly due to decreased efficiency and restriction in time devoted to work. ${ }^{4}$ Patients also tended to miss other activities, such as family, social, and leisure activities, even more than school and work. ${ }^{5}$ These results for EVOLVE-1 and -2 demonstrated that galcanezumab treatment improved patient functioning across multiple areas of life. As measured by the MSQ the amount of time that migraine restricted, prevented, or emotionally impaired patients in usual daily activities such as work and social events was significantly decreased.

Previous studies showed that migraine preventive treatments from various drug classes improved patient functioning and reduced disability. ${ }^{18,32,33}$ Comparisons between studies are limited by differences in methodologies. In the EVOLVE-1 and -2 trials, significant improvements in MSQv2.1 compared with placebo were observed early for galcanezumab (month 1 ). In a pooled analysis of 3 clinical studies of topiramate, which requires 4 weeks of dose titration up to $100 \mathrm{mg} / \mathrm{d}, \mathrm{MSQv} 2.1$ responses were not collected before 8 weeks. ${ }^{17}$ In a clinical study comparing topiramate and amitriptyline, MIDAS score reductions averaged 12 and 14 points after 6 months. ${ }^{32}$ The average decrease observed with galcanezumab in EVOLVE-1 and -2 was of greater magnitude ( -20 points). A recent clinical trial of erenumab demonstrated significant reductions in
MIDAS scores after 3 months of treatment, although a modified version of MIDAS was used. ${ }^{33}$ Overall, these studies showed that galcanezumab treatment yielded improvements in patient functioning and reductions in disability associated with migraine that were consistent with other migraine preventive treatments. Continued research is needed to observe the clinical implications of achieving improvements as early as 1 month after initiating treatment.

Studies have shown that migraine-preventive medications improve workplace efficiency, decrease missed workdays, improve HRQoL, and reduce activity limitations. ${ }^{4,34}$ Data from these 2 studies showed significant and clinically meaningful reductions in functional impairment and disability when patients were treated with galcanezumab and thus suggest the potential to increase work productivity.

There are limitations to this research. Whether these findings can be applied to the broader general episodic migraine population is not known, but the baseline characteristics of these clinical study patients were similar to those described elsewhere. ${ }^{5}$ Furthermore, galcanezumab was tested as a monotherapy and the HRQoL outcomes when used concurrently with other preventive medications are not yet known. The occurrence of migraine headaches per month tends to vary over time for patients ${ }^{35}$ and an adequate time on treatment is needed to observe changes in patient functioning; therefore, the average of months 4-6 was used as the endpoint for the MSQ to increase accuracy and to allow for a more stable endpoint estimate. However, these studies were designed with a 1-month prospective baseline period and it was not feasible to capture an average over multiple months at baseline, to account for potential variability prior to randomization.

These results provide important evidence for clinicians and health care policy makers that, beyond decreasing the number of MHD, galcanezumab improved patients' health-related quality of life scores and improved disability scores in a rapid and sustained fashion.

\section{Acknowledgment}

The authors thank the study participants, site investigators, and personnel involved in these studies.

\section{Study funding}

Funding was provided by Eli Lilly and Company, Indianapolis, IN.

\section{Disclosure}

J. Ford is a full-time employee of Eli Lilly and Company and minority owner of company stock. D. Ayer is a full-time employee of Eli Lilly and Company and minority owner of company stock. Q. Zhang was previously a full-time employee of Eli Lilly and Company and is a minority owner of company stock. Q. Zhang is now a full-time employee of Sanofi. J. Carter was previously a full-time employee of Eli Lilly and Company and is a minority owner of company stock. J.N. Carter is 
a full-time employee of Elanco. E. Leroux has received compensation for serving on advisory boards, speaking, and/or consulting from Allergan, Eli Lilly and Company, Novartis, Tribute Pharmaceuticals, and Teva Neurosciences. V. Skljarevski is a full-time employee of Eli Lilly and Company and minority owner of company stock. S. Aurora is a full-time employee of Eli Lilly and Company and minority owner of company stock. A. Tockhorn-Heidenreich is a fulltime employee of Eli Lilly and Company and minority owner of company stock. R. Lipton is the Edwin S. Lowe Professor of Neurology at the Albert Einstein College of Medicine in New York; receives research support from the NIH: 2PO1 AG003949 (Program Director), 5 U10 NS077308 (PI), RO1 NS082432 (Investigator), 1RF1 AG057531 (Site PI), RF1 AG054548 (Investigator), 1RO1 AG048642 (Investigator), R56 AG057548 (Investigator), K23 NS09610 (Mentor), K23AG049466 (Mentor), and 1K01AG054700 (Mentor); receives support from the Migraine Research Foundation and the National Headache Foundation; serves on the editorial board of Neurology, senior advisor to Headache, and associate editor to Cephalalgia; has reviewed for the NIA and NINDS; holds stock options in eNeura Therapeutics and Biohaven Holdings; serves as consultant, advisory board member, or has received honoraria from American Academy of Neurology, Alder, Allergan, American Headache Society, Amgen, Autonomic Technologies, Avanir, Biohaven, Biovision, Boston Scientific, Dr. Reddy's, Electrocore, Eli Lilly and Company, eNeura Therapeutics, GlaxoSmithKline, Merck, Pernix, Pfizer, Supernus, Teva, Trigemina, Vector, and Vedanta; and receives royalties from Wolffs Headache 7th and 8th edition, Oxford Press University, 2009, Wiley and Informa. Go to Neurology.org/ $\mathrm{N}$ for full disclosures.

\section{Publication history}

Received by Neurology August 14, 2018. Accepted in final form March 14, 2019.

\section{Appendix Authors}

\begin{tabular}{|c|c|c|c|}
\hline Name & Location & Role & Contribution \\
\hline $\begin{array}{l}\text { Janet H. Ford, } \\
\text { PhD }\end{array}$ & $\begin{array}{l}\text { Eli Lilly \& Company, } \\
\text { Indianapolis }\end{array}$ & Author & $\begin{array}{l}\text { Study design, } \\
\text { interpretation of } \\
\text { the data, wrote the } \\
\text { initial draft of the } \\
\text { manuscript, and } \\
\text { revised the manuscript } \\
\text { for content }\end{array}$ \\
\hline $\begin{array}{l}\text { David W. } \\
\text { Ayer, PhD }\end{array}$ & $\begin{array}{l}\text { Eli Lilly \& Company, } \\
\text { Indianapolis }\end{array}$ & Author & $\begin{array}{l}\text { Study design, } \\
\text { interpretation of } \\
\text { the data, wrote the } \\
\text { initial draft of the } \\
\text { manuscript, and } \\
\text { revised the manuscript } \\
\text { for content }\end{array}$ \\
\hline $\begin{array}{l}\text { Qi Zhang, } \\
\text { PhD }\end{array}$ & $\begin{array}{l}\text { Formerly Eli Lilly \& } \\
\text { Company, } \\
\text { Indianapolis; } \\
\text { currently Sanofi, } \\
\text { Bridgewater }\end{array}$ & Author & $\begin{array}{l}\text { Study design, } \\
\text { interpretation of the } \\
\text { data, contributed to } \\
\text { the analysis of the } \\
\text { data, and revised the } \\
\text { manuscript for } \\
\text { content }\end{array}$ \\
\hline
\end{tabular}

Appendix (continued)

\begin{tabular}{|c|c|c|c|}
\hline Name & Location & Role & Contribution \\
\hline $\begin{array}{l}\text { Jeffrey N. } \\
\text { Carter, PhD }\end{array}$ & $\begin{array}{l}\text { Formerly Eli Lilly \& } \\
\text { Company, } \\
\text { Indianapolis; } \\
\text { currently Elanco, } \\
\text { Indianapolis }\end{array}$ & Author & $\begin{array}{l}\text { Interpretation of the } \\
\text { data, wrote the initial } \\
\text { draft of the } \\
\text { manuscript, revised } \\
\text { the manuscript for } \\
\text { content, prepared } \\
\text { the manuscript for } \\
\text { submission }\end{array}$ \\
\hline $\begin{array}{l}\text { Elizabeth } \\
\text { Leroux, MD }\end{array}$ & University of Calgary & Author & $\begin{array}{l}\text { Contributed to } \\
\text { creating the } \\
\text { manuscript and } \\
\text { revising it for } \\
\text { intellectual content }\end{array}$ \\
\hline $\begin{array}{l}\text { Vladimir } \\
\text { Skljarevski, } \\
\text { MD }\end{array}$ & $\begin{array}{l}\text { Eli Lilly \& Company, } \\
\text { Indianapolis }\end{array}$ & Author & $\begin{array}{l}\text { Study design, } \\
\text { interpretation of the } \\
\text { data, and revised the } \\
\text { manuscript for } \\
\text { content }\end{array}$ \\
\hline $\begin{array}{l}\text { Sheena K. } \\
\text { Aurora, MD }\end{array}$ & $\begin{array}{l}\text { Eli Lilly \& Company, } \\
\text { Indianapolis }\end{array}$ & Author & $\begin{array}{l}\text { Contributed to } \\
\text { creating and revising } \\
\text { the manuscript for } \\
\text { content }\end{array}$ \\
\hline $\begin{array}{l}\text { Antje } \\
\text { Tockhorn- } \\
\text { Heidenreich, } \\
\text { MSc }\end{array}$ & $\begin{array}{l}\text { Eli Lilly \& Company, } \\
\text { Indianapolis }\end{array}$ & Author & $\begin{array}{l}\text { Contributed to } \\
\text { creating and revising } \\
\text { the manuscript for } \\
\text { content }\end{array}$ \\
\hline $\begin{array}{l}\text { Richard B. } \\
\text { Lipton, MD }\end{array}$ & $\begin{array}{l}\text { Albert Einstein } \\
\text { College of Medicine, } \\
\text { Bronx }\end{array}$ & Author & $\begin{array}{l}\text { Contributed to } \\
\text { creating the } \\
\text { manuscript and } \\
\text { revising it for } \\
\text { intellectual } \\
\text { content }\end{array}$ \\
\hline
\end{tabular}

\section{References}

1. Global Burden of Disease Neurological Disorders Collaborator Group. Global, regional, and national burden of neurological disorders during 1990-2015: a systematic analysis for the global burden of disease study 2015. Lancet Neurol 2017; 16:877-897.

2. D’Amico D, Grazzi L, Usai S, Leonardi M, Raggi A. Disability and quality of life in headache: where we are now and where we are heading. Neurol Sci 2013;34(Suppl 1): S1-S5.

3. Chaushev N, Milanov I. Impact of migraine and migraine treatment on patient's capacity to work and quality of life. J Clin Med 2009;2009:26-31.

4. Raggi A, Giovannetti AM, Quintas R, et al. A systematic review of the psychosocial difficulties relevant to patients with migraine. J Headache Pain 2012; 13:595-606.

5. Abu Bakar N, Tanprawate S, Lambru G, Torkamani M, Jahanshahi M, Matharu M. Quality of life in primary headache disorders: a review. Cephalalgia 2016;36: 67-91.

6. Matchar DB, Harpole L, Samsa GP, et al. The headache management trial: a randomized study of coordinated care. Headache 2008;48:1294-1310.

7. Lipton RB, Stewart WF, Sawyer J, Edmeads JG. Clinical utility of an instrument assessing migraine disability: the Migraine Disability Assessment (MIDAS) questionnaire. Headache 2001;41:854-861.

8. Blumenfeld AM, Bloudek LM, Becker WJ, et al. Patterns of use and reasons for discontinuation of prophylactic medications for episodic migraine and chronic migraine: results from the second International Burden of Migraine Study (IBMS-II). Headache 2013;53:644-655.

9. Estemalik E, Tepper S. Preventive treatment in migraine and the new US guidelines. Neuropsychiatr Dis Treat 2013;9:709-720.

10. Stauffer VL, Dodick DW, Zhang Q, Carter JN, Ailani J, Conley RR. Evaluation of galcanezumab for the prevention of episodic migraine: the EVOLVE-1 randomized clinical trial. JAMA Neurol 2018;75:1080-1088.

11. Skljarevski V, Matharu M, Millen BA, Ossipov MH, Kim BK, Yang JY. Efficacy and safety of galcanezumab for the prevention of episodic migraine: results of the EVOLVE-2 Phase 3 randomized controlled clinical trial. Cephalalgia 2018;38: $1442-1454$.

12. Headache Classification Committee of the International Headache Society. The International Classification of Headache Disorders, 3rd edition (beta version). Cephalalgia 2013;33:629-808. 
13. Cole JC, Lin P, Rupnow MF. Validation of the Migraine-Specific Quality of Life Questionnaire version 2.1 (MSQ v. 2.1) for patients undergoing prophylactic migraine treatment. Qual Life Res 2007;16:1231-1237.

14. Rendas-Baum R, Bloudek LM, Maglinte GA, Varon SF. The psychometric propertie of the Migraine-Specific Quality of Life Questionnaire version 2.1 (MSQ) in chronic migraine patients. Qual Life Res 2013;22:1123-1133.

15. Jhingran P, Davis SM, LaVange LM, Miller DW, Helms RW. MSQ: Migraine-Specific Quality-of-Life Questionnaire: further investigation of the factor structure. Pharmacoeconomics 1998;13:707-717.

16. Jhingran P, Osterhaus JT, Lee JT, Kirchdoerfer L. Development and validation of the Migraine-Specific Quality of Life Questionnaire. Headache 1998;38:295-302.

17. Dahlöf C, Loder E, Diamond M, Rupnow M, Papadopoulos G, Mao L. The impact of migraine prevention on daily activities: a longitudinal and responder analysis from three topiramate placebo-controlled clinical trials. Health Qual Life Outcomes 2007;5:56.

18. Lipton RB, Varon SF, Grosberg B, et al. OnabotulinumtoxinA improves quality of life and reduces impact of chronic migraine. Neurology 2011;77:1465-1472.

19. Bagley CL, Rendas-Baum R, Maglinte GA, Yang SF, Lee J, Kosinski M. Validating Migraine-Specific Quality of Life Questionnaire v2.1 in episodic and chronic migraine. Headache 2012;52:409-421

20. Martin BC, Pathak DS, Sharfman MI, Adelman F, Kwong WJ, Jhingran P. Validity and reliability of the Migraine-Specific Quality of Life Questionnaire (MSQVersion 2.1). Headache 2000;40:204-215.

21. Mulleners WM, McCrory DC, Linde M. Antiepileptics in migraine prophylaxis: an updated Cochrane review. Cephalalgia 2015;35:51-62.

22. National Institute of Neurological Disorders and Stroke. Summary of core and supplemental-highly recommended recommendations: headache CDEs [online]. Available at: commondataelements.ninds.nih.gov/Doc/Headache/CDEStartupResource_Headache.pdf. Accessed December 11, 2018.

23. Dodick DW, Silberstein S, Saper J, et al. The impact of topiramate on health-related quality of life indicators in chronic migraine. Headache 2007;47:1398-1408.

24. Stewart WF, Lipton RB, Kolodner K, Liberman J, Sawyer J. Reliability of the Migraine Disability Assessment Score in a population-based sample of headache sufferers. Cephalalgia 1999;19:107-114; discussion 174
25. Stewart WF, Lipton RB, Dowson AJ, Sawyer J. Development and testing of the Migraine Disability Assessment (MIDAS) questionnaire to assess headache-related disability. Neurology 2001;56:S20-S28.

26. Raggi A, Leonardi M, Bussone G, D’Amico D. Value and utility of disease-specific and generic instruments for assessing disability in patients with migraine, and their relationships with health-related quality of life. Neurol Sci 2011;32:387-392.

27. Food and Drug Administration. Guidance for Industry: Patient-Reported Outcome Measures: Use in Medical Product Development to Support Labeling Claims. College Park: Federal Register: US Government; 2009:65132-65133.

28. Speck R, Shalhoub H, Ayer D, Ford J, Wyrwich K, Bush E. Psychometric validation of the MSQv2.1 ePRO for use in patients with episodic and chronic migraine (PF84). 60th Annual Scientific Meeting, American Headache Society; San Francisco; 2018: 127.

29. Linde M, Gustavsson A, Stovner LJ, et al. The cost of headache disorders in Europe: the Eurolight project. Eur J Neurol 2012;19:703-711.

30. Serrano D, Manack AN, Reed ML, Buse DC, Varon SF, Lipton RB. Cost and predictors of lost productive time in chronic migraine and episodic migraine: results from the American Migraine Prevalence and Prevention (AMPP) Study. Value Health 2013;16:31-38.

31. Buse DC, Scher AI, Dodick DW, Reed KM, Manack Adams A, Lipton RB. Impact of migraine on the family: perspectives of people with migraine and their spouse/ domestic partner in the CaMEO study. Mayo Clin Proc Epub 2016 Apr 25.

32. Dodick DW, Freitag F, Banks J, et al. Topiramate versus amitriptyline in migraine prevention: a 26-week, multicenter, randomized, double-blind, double-dummy, parallelgroup noninferiority trial in adult migraineurs. Clin Ther 2009;31:542-559.

33. Dodick DW, Ashina M, Brandes JL, et al. ARISE: a phase 3 randomized trial of erenumab for episodic migraine. Cephalalgia 2018;38:1026-1037.

34. D'Amico D, Solari A, Usai S, et al. Improvement in quality of life and activity limitations in migraine patients after prophylaxis: a prospective longitudinal multicentre study. Cephalalgia 2006;26:691-696.

35. Serrano D, Lipton RB, Scher AI, Reed WBF, Adams AM, Buse DC. Fluctuations in episodic and chronic migraine status over the course of 1 year: implications for diagnosis, treatment and clinical trial design. J Headache Pain 2017;18:101. 


\section{Neurology}

\section{Two randomized migraine studies of galcanezumab: Effects on patient functioning and disability}

Janet H. Ford, David W. Ayer, Qi Zhang, et al.

Neurology 2019;93;e508-e517 Published Online before print July 3, 2019

DOI 10.1212/WNL.0000000000007856

\section{This information is current as of July 3, 2019}

\section{Updated Information \& Services}

References

Citations

Subspecialty Collections

Permissions \& Licensing

Reprints including high resolution figures, can be found at: http://n.neurology.org/content/93/5/e508.full

This article cites 31 articles, 2 of which you can access for free at: http://n.neurology.org/content/93/5/e508.full\#ref-list-1

This article has been cited by 1 HighWire-hosted articles: http://n.neurology.org/content/93/5/e508.full\#\#otherarticles

This article, along with others on similar topics, appears in the following collection(s):

\section{Migraine}

http://n.neurology.org/cgi/collection/migraine

Outcome research

http://n.neurology.org/cgi/collection/outcome_research

Quality of life

http://n.neurology.org/cgi/collection/quality_of_life

Information about reproducing this article in parts (figures,tables) or in its entirety can be found online at:

http://www.neurology.org/about/about_the_journal\#permissions

Information about ordering reprints can be found online:

http://n.neurology.org/subscribers/advertise

Neurology ${ }^{\circledR}$ is the official journal of the American Academy of Neurology. Published continuously since 1951, it is now a weekly with 48 issues per year. Copyright Copyright ( 2019 The Author(s). Published by Wolters Kluwer Health, Inc. on behalf of the American Academy of Neurology.. All rights reserved. Print ISSN: 0028-3878. Online ISSN: 1526-632X.

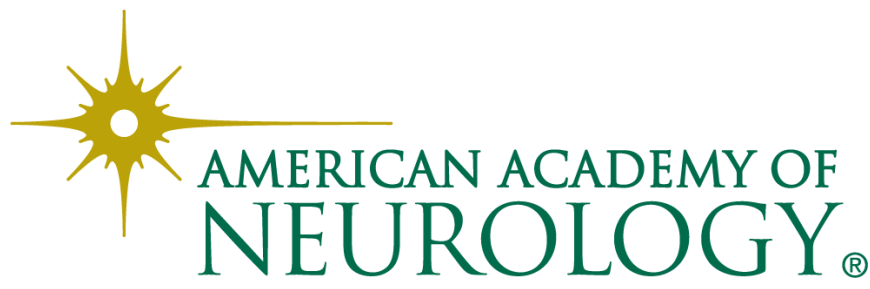

